\title{
Prepatellar septic bursitis in an 8-year-old boy
}

\author{
Akihiro Iguchi, ${ }^{1}$ Yoshihiro Aoki, ${ }^{1,2}$ Katsuhiko Kitazawa'
}

${ }^{1}$ Department of Pediatrics, Asahi General Hospital, Asahi, Chiba, Japan

${ }^{2}$ Department of Intensive Care Medicine, Osaka Women's and Children's Hospital, Izumi,

\section{Correspondence to} Dr Akihiro Iguchi, iguchi-sig@umin.ac.jp

Accepted 12 December 2018 Osaka, Japan

\section{DESCRIPTION}

A bursa is a cellular membrane overlying bony prominences (eg, prepatellar bursa or olecranon). Bursitis is inflammation in the bursa of the knee or elbow, with septic or non-septic origin. Acute accidental trauma can lead to an infected bursa ${ }^{2}$ whereas non-septic causes include Osgood-Schlatter disease, juvenile rheumatoid arthritis and sports-related trauma. ${ }^{2}$ It is important to differentiate septic bursitis from arthritis and osteomyelitis in terms of severe bacterial infection. Paediatric septic bursitis, however, is extremely rare, and therefore the diagnosis can be challenging.

An 8-year-old boy without any medical history visited the emergency department with right knee pain for 2 days and fever for 1 day. He denied any trauma prior to the consultation. On admission, his temperature was $38.2^{\circ} \mathrm{C}$, heart rate was 110 beats/min, respiratory rate was 20 and oxygen saturation was $100 \%$ on room air. Physical examination showed tenderness, swelling and mild redness on the front of the knee, and difficulty in gait. There were no abnormal eczematous skin lesions or abnormalities of the knee joint, and the range of motion was intact. Blood test showed that white cell count (WCC) was $11 \times 10^{9} / \mathrm{L}$ and C-reactive protein $0.08 \mathrm{mg} / \mathrm{dL}$. X-ray film of the knee showed no abnormality. Although synovial fluid was not aspirated by knee puncture, bursal fluid

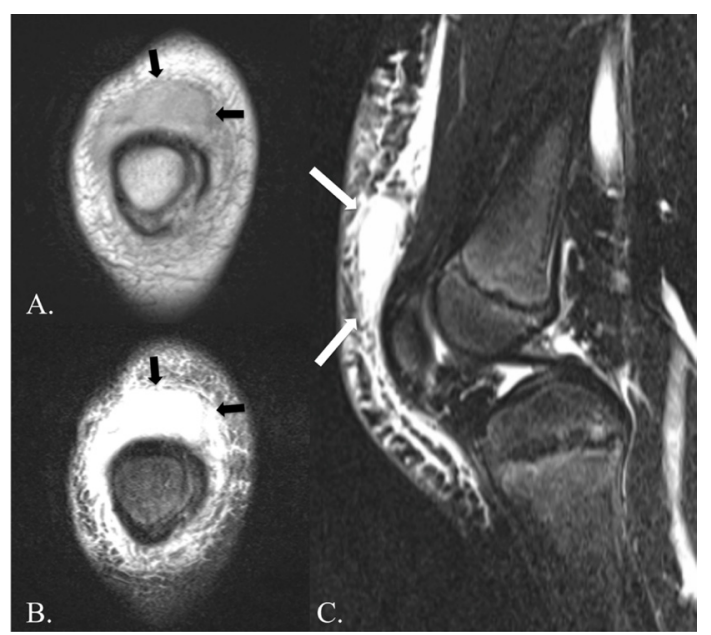

(c) BMJ Publishing Group Limited 2019. No commercial re-use. See rights and permissions. Published by BMJ.

To cite: Iguchi A, Aoki Y, Kitazawa K. BMJ Case Rep 2019;12:e228564 doi:10.1136/bcr-2018 228564
Figure 1 (A) Coronal view; proton density-weighted MRI scan showing an area of hypointensity area in the prepatellar bursae (black arrow). (B) Coronal view; T2weighted MRI scan showing an area of hyperintensity area in the prepatellar bursae (black arrow). (C) Sagittal view; short-T1 inversion recovery MRI scan showing highintensity area in the prepatellar bursae (white arrow). Unremarkable findings in the patella and the joint. was purulent (WCC $123 \times 10^{9} / \mathrm{L}$ ). As Gram stain revealed Gram-positive Staphylococci, cefazolin was administrated. MRI of the knee showed no significant abnormalities in the joint space, but there was accumulation of fluid in the prepatellar bursa (figure 1A-C). Methicillin-susceptible Staphylococcus aureus was detected in the synovial fluid culture, confirming the diagnosis of septic bursitis. Blood culture on admission was negative. Fever reduced on the third day of hospitalisation and local findings also improved. He received cefazolin for 12 days followed by cephalexin for 2 days. No recurrence was observed after 1 year.

In this case, MRI helped in early definitive diagnosis, excluding arthritis or osteomyelitis. The duration of treatment for septic bursitis, septic arthritis and osteomyelitis is different. Uncomplicated septic bursitis requires oral treatment, ${ }^{3}$ whereas some cases may require several rounds of drainage or bursectomy. ${ }^{1}$ Furthermore, if treatment is not correct, septic bursitis may result in osteomyelitis that can lead to further bony destruction. ${ }^{1}$ Therefore, early diagnosis with correct examination, prompt Gram staining and MRI imaging, and early treatment are essential in the management of septic bursitis.

\section{Learning points}

- Bursitis is inflammation in the bursa of the knee or elbow, with septic or non-septic origin.

- Paediatric septic bursitis is extremely rare, and the diagnosis can be challenging.

- MRI is useful to differentiate septic bursitis from septic arthritis and osteomyelitis.

Contributors Al managed the patient, drafted the initial manuscript and approved the final manuscript prior to submission. YA critically reviewed and revised the manuscript and approved the final manuscript prior to submission. KK revised the manuscript and approved the final manuscript prior to submission.

Funding The authors have not declared a specific grant for this research from any funding agency in the public, commercial or not-for-profit sectors.

Competing interests None declared.

Patient consent Obtained.

Provenance and peer review Not commissioned; externally peer reviewed.

\section{REFERENCES}

1 Kratimenos P, Koutroulis I, Marconi D, et al. Septic bursitis in an 8-year-old boy. Case Rep Pediatr 2014;2014:1-4.

2 Harwell Jl, Fisher D. Pediatric septic bursitis: case report of retrocalcaneal infection and review of the literature. Clin Infect Dis 2001:32:e102-e104.

3 Choi HR. Patellar osteomyelitis presenting as prepatellar bursitis. Knee 2007;14:333-5. 
Copyright 2018 BMJ Publishing Group. All rights reserved. For permission to reuse any of this content visit https://www.bmj.com/company/products-services/rights-and-licensing/permissions/

BMJ Case Report Fellows may re-use this article for personal use and teaching without any further permission.

Become a Fellow of BMJ Case Reports today and you can:

- Submit as many cases as you like

- Enjoy fast sympathetic peer review and rapid publication of accepted articles

Access all the published articles

- Re-use any of the published material for personal use and teaching without further permission

For information on Institutional Fellowships contact consortiasales@bmjgroup.com

Visit casereports.bmj.com for more articles like this and to become a Fellow 